\title{
Main Agro-Morphological and Biochemical Berry Characteristics of Wild-Grown Sea Buckthorn (Hippophae rhamnoides L. ssp. caucasica Rousi) Genotypes in Turkey
}

\author{
Gülçe Ilhan ${ }^{1}$, Muttalip Gundogdu ${ }^{2}$ (D) Ksenija Karlović $^{3}$, Vesna Židovec ${ }^{3}$, Aleš Vokurka ${ }^{4, *}$ and Sezai Ercişli ${ }^{1}$ (D) \\ 1 Department of Horticulture, Agricultural Faculty, Ataturk University, 25240 Erzurum, Turkey; \\ gulceilhan07@gmail.com (G.I.); sercisli@gmail.com (S.E.) \\ 2 Department of Horticulture, Agriculture and Natural Sciences Faculty, Bolu Abant Izzet Baysal University, \\ 14030 Bolu, Turkey; gundogdumuttalip@gmail.com \\ 3 Department of Ornamental Plants, Landscape Architecture and Garden Art, Faculty of Agriculture, \\ University of Zagreb, 10000 Zagreb, Croatia; karlovic@agr.hr (K.K.); vzidovec@agr.hr (V.Ž.) \\ 4 Department of Plant Breeding, Genetics and Biometrics, Faculty of Agriculture, University of Zagreb, \\ 10000 Zagreb, Croatia \\ * Correspondence: avokurka@agr.hr; Tel.: +385-1-2394087
}

check for updates

Citation: Ilhan, G.; Gundogdu, M.; Karlović, K.; Židovec, V.; Vokurka, A.; Ercişli, S. Main Agro-Morphological and Biochemical Berry Characteristics of Wild-Grown Sea Buckthorn (Hippophae rhamnoides L. ssp. caucasica Rousi) Genotypes in Turkey. Sustainability 2021, 13, 1198. https:// doi.org/10.3390/su13031198

Academic Editors: Marc A. Rosen and Francesco Sottile

Received: 4 November 2020

Accepted: 20 January 2021

Published: 24 January 2021

Publisher's Note: MDPI stays neutral with regard to jurisdictional claims in published maps and institutional affiliations.

Copyright: (c) 2021 by the authors. Licensee MDPI, Basel, Switzerland. This article is an open access article distributed under the terms and conditions of the Creative Commons Attribution (CC BY) license (https:/ / creativecommons.org/licenses/by/ $4.0 /)$.

\begin{abstract}
Sea buckthorn (Hippophae rhamnoides L. ssp. caucasica Rousi) is one of the most important wild edible fruits, grown in Turkey for centuries without any chemical treatments. The plant is extremely resistant to adverse environmental conditions. In this study, the main agro-morphological and biochemical berry traits and, to a lesser extent, other plant morphological traits of 10 sea buckthorn genotypes sampled from the eastern Anatolia (Sivas province) region were assessed. Among the 10 genotypes, five of them presented a shrub growth habit, whereas five of them presented tree growth habit, with leaf area ranging from 2.56 to $4.22 \mathrm{~cm}^{2}$. The majority of genotypes had an oblong berry shape with variable berry skin color ranging from dark orange to orange, light orange, and yellow. The weight of 100 berries varied from 13.85 to $23.87 \mathrm{~g}$, while juice yield and vitamin C content was found to be $44.87-57.15 \%$ and $37.45-62.85 \mathrm{mg} / 100 \mathrm{~g}$ fresh berry base, respectively. Soluble solid content (SSC) was in the range of $12.56-14.67 \%$. The genotypes exhibited a great variability in total anthocyanin content (from 9.1 to $38.7 \mathrm{mg} / \mathrm{L}$ ), with relatively dark-orange sea buckthorn berries containing more anthocyanin than orange, light-orange, and yellow berries. Linoleic acid was the main fatty acid detected in the pulp of sea buckthorn berries, ranging from $24.11 \%$ to $36.37 \%$, depending on the genotype. Investigated genotypes proved also to be rich in total phenolic content, showing at the same time great variability in this trait. The results obtained from the relatively limited number of genotypes show promising traits for further valorization of both horticultural and nutritional traits, suggesting potentially even higher variability, if more genotypes are going to be considered in the future.
\end{abstract}

Keywords: sea buckthorn; biodiversity; biochemical composition; underutilized fruit

\section{Introduction}

Wild edible fruits have attracted great attention in recent years. They include a large number of species and genotypes and exhibit a rich biodiversity. The fruits of these species are very rich in terms of vitamins, minerals, dietary fibers, anthocyanins, phenolics, etc. Moreover, for centuries, particularly in rural areas, people used stems, leaves, flowers, and roots of wild edible fruits because of their high potential in traditional medicine [1-3]. More recently, the majority of wild edible fruits, including sea buckthorn, have been labeled as functional foods, which denotes foods used not only for nutrition but also for prevention and cure of various diseases [4-6].

Turkey is accepted as one of the richest countries in wild edible fruits, which played an important role in rural people's life for centuries. Rural communities used wild edible 
fruits not only fresh but also processed into several natural products such as molasses, syrups, jams, candied peels, and vinegars [7,8]. In Turkey, it is estimated that there are over 100 wild edible fruit species, and it is well known that they are an integral part of everyday life of Turkish people [9]. In Turkey, nearly one-quarter of the total population lives in rural areas where food shortages are frequent, even in close history, and a large number of these agricultural communities still retain a habit of using wild edible fruits. The rural areas are frequently characterized by harsh climatic conditions coupled with poor crop harvests. Thus, the wild edible fruits are vital for the existence of rural people, and they are frequently educated to rely on wild edible fruits for survival [10-12]. Sea buckthorn shows great diversity in Turkey's flora, and, in general, it occurs in natural stands, mainly in inner, northern, and eastern Anatolia [13].

Sea buckthorn (Hippophae rhamnoides L.), which grows in a form of a tree or a shrub, belongs to the Oleaster family (Eleagnaceae) and is mostly found in a broad area of eastern and western Asia, eastern, central, and northern Europe, from the Caucasus to the Carpathian Mountains and northern America including Canada [14-16]. In general, it is found as wild in the fields; however, in some countries such as Sweden, Finland, China, Poland, Romania, Ukraine, Germany, Hungary, Belarus, Russia, Azerbaijan, Czech Republic, and Canada, it was domesticated in the last few centuries due to its valuable horticultural and multiple-use berry characteristics $[11,17]$. Subspecies, H. rhamnoides L. ssp. caucasica Rousi is the only Hippophae species growing in Turkey and is generally considered as morphologically quite variable $[18,19]$.

All parts of the sea buckthorn plant have broad application. Due to its diverse and attractive shrub and tree characteristics, colorful berries, and narrow silvery leaves, it has considerable ornamental value. Because edible berries are consumed by animals, sea buckthorn is also used for enhancing wildlife habitats. The plant has a great environmental plasticity; thus, it can be used for afforestation and wasteland management, which has led to its large-scale planting. It is resistant to urban conditions. Furthermore, as a xerophyte species, it tolerates drought, cold (up to $-40{ }^{\circ} \mathrm{C}$ ), heat (up to $40{ }^{\circ} \mathrm{C}$ ), soil salinity, and air pollution $[16,20]$. Sea buckthorn is a fruit species with a high nitrogen fixation capacity, thus improving soil quality; moreover, because of its extensive root system, it exhibits soil-binding properties [21,22].

Sea buckthorn berries are accepted as a "super food" or "powerful food". The berries have a high amount of proteins, fibers, antioxidants, vitamins (A, C, E), minerals, flavonoids (flavanas), ether oil, organic acids, saponin, and sugar. Berries of sea buckthorn are also used in plant-based medicines because of their valuable contents $[23,24]$. The leaves, flowers, seeds, and berries of sea buckthorn are used for medicinal purposes [25]. Sea buckthorn boasts all the omega (3, 6, 9 and rare omega-7) essential fatty acids. Furthermore, the pulp of sea buckthorn berries is one of the richest plant sources in the world of omega-7 essential fatty acids [26-28]. The attractive orange color of sea buckthorn berries can be attributed to beta-carotene, a type of carotenoid. Beta-carotene is the most common type of pro-vitamin A found mainly in plant-based foods [15].

Sea buckthorn genotypes have diverse morphological, biochemical, and phenological characteristics, and these characteristics differ from one genotype to another one due to dioicous flowering biology. Each seed-propagated genotype has its own characteristics, and these agro-morphologic and biochemical properties are the basic criteria used to define the genotypes; agro-morphological and biochemical characterizations have been used for a long time, particularly by the breeders $[11,15,16,22]$.

More recently, the use of wild-grown plants as food sources has been a hot topic for researchers globally, and the traditional use of natural plant resources, with minimal ecosystem alteration, is the preferred, emerging approach. Therefore, in this study, we attempted to determine the basic agro-morphological and biochemical traits of 10 seedpropagated sea buckthorn genotypes that grow naturally in the flora of Sivas province, located in eastern Anatolia. To our knowledge, the scientific literature available related to the agro-morphological and biochemical traits of this wild edible fruit grown in Turkey is 
scarce. We assume that the obtained results may support breeders' efforts with improved knowledge about the agro-morphological and detailed biochemical properties of diverse sea buckthorn genotypes that could be integrated in future breeding programs of this prominent, but still less utilized species.

\section{Materials and Methods}

\subsection{Plant Materials}

Ten promising genotypes of Hippophae rhamnoides L. ssp. caucasica growing in Sivas province, located at $37^{\circ} 01^{\prime}$ east longitude, $39^{\circ} 75^{\prime}$ north latitude, were chosen according to field observations on the basis of high yield capacity, pest and disease resistance, and attractive berries. In fact, sea buckthorn plants are constantly selected in the fields by farmers who eliminate the bad ones, leaving only the superior plants. Thus, 10 buckthorn genotypes, previously "farmer-selected", were chosen for analysis, each represented with one plant (tree or shrub). All the plants were growing at a similar altitude of $1000 \pm 50 \mathrm{~m}$ above sea level (a.s.l.).

Sivas province has a continental climate (Köppen climate classification: Dsb) with warm dry summers and cold and snowy relatively long winters. Sea buckthorn plants are abundant in the province and create an important part of the natural landscape of Sivas territory. Local communities have used them for centuries, both as food and in traditional medicine.

In total, $400 \mathrm{~g}$ of berries and 100 leaves per genotype were randomly harvested from different parts of the crown and divided into an appropriate number of replicates for different agro-morphological or biochemical analyses.

The berries were harvested in the field when fully ripened, i.e., when they reached their characteristic mature berry skin color and possessed enough sweetness and softness to make them more palatable. The berry and leaf samples taken from each of the sea buckthorn genotypes (trees or shrubs) were labeled, placed into appropriate containers, and immediately transferred to the laboratory. The agro-morphological measurements were done immediately, while the berry samples to be used for biochemical analysis were kept in ultra-low-temperature freezers at $-80{ }^{\circ} \mathrm{C}$ until analysis.

\subsection{Agro-Morphological Measurements}

In the field, the growth habit and presence of thorns were determined. In the laboratory, the berry skin color, 100-berry weight, berry shape, and leaf area $\left(\mathrm{cm}^{2}\right)$ of 10 genotypes were determined by using 100 leaves and 100 berries per genotype, which were divided into replicates (20 berries per replicate). A trained panel of five experts evaluated visible berry skin color for each genotype. The 1-5 bipolar hedonic scale was used to describe berry skin color [2,3], which was rated as light yellow, yellow, light orange, orange, or dark orange. Berry weight was measured on 100 berries per genotype using a digital balance with a sensitivity of $0.001 \mathrm{~g}$ (Scaltec SPB31). Berry length and berry diameter were measured using the digital caliper gauge, once after the harvest, on the longest and the widest point of the berry. The berry shape was determined by using the berry diameter-and-length ratio. Leaf area was measured with a portable laser leaf area meter (Area meter CI 201, Li-Cor Biosciences, Lincoln, NE, USA).

\subsection{Juice Yield, SSC (Soluble Solid Content), Vitamin C, Protein, and Lipid}

Juice yield, SSC, vitamin C, protein, and lipid content was determined on $100 \mathrm{~g}$ of berries per genotype, divided into four replicates ( $25 \mathrm{~g}$ per replicate). Juice yield in the berries of the 10 sea buckthorn genotypes was determined by using pressure extraction, calculated according to Tiitinen et al. [29]. Fruit juice soluble solid content (SSC) was determined using a digital refractometer (Kyoto Electronics Manufacturing Co. Ltd., Kyoto, Japan, Model RA-250 HE). The titratable acidity and vitamin C content of sea buckthorn berries was determined using a RQFlex 10 Reflectometer (Merck, Darmstadt, Germany). The total protein and lipid content of genotypes was determined by AOAC [30]. The 
Kjeldahl method was used for total protein content determination of sea buckthorn berries, and Soxhlet extraction was used for lipid determination.

\subsection{Extraction and Determination of Specific Sugars}

For determination of specific sugars, the procedure of Melgarejo et al. [31] was followed. A total of $10 \mathrm{~g}$ of each sea buckthorn berry sample was centrifuged at 12,000 rpm for $2 \mathrm{~min}$ at $4{ }^{\circ} \mathrm{C}$. Afterward, the supernatant was filtered with a SEP-PAK C18 cartridge and transferred into a vial for analysis. The standards were used for quantification of the concentrations. Analysis of sugars was performed by HPLC (isocratic program) with a Bondapak- $\mathrm{NH}_{2}$ column ( $\mu$ g Bondapak/carbohydrate) and a refractive index (RI) detector using $85 \%$ acetonitrile as a mobile phase. The calculation of concentrations was based on standards prepared in the laboratory. The mobile phase was acetonitrile/water (85/15) with a flow rate of $1 \mathrm{~mL} / \mathrm{min}$, at ambient temperature. Sugars were detected at $210 \mathrm{~nm}$. In calibration curves, standard sugar solutions (glucose, fructose, and sucrose) were prepared to contain between $10 \mu \mathrm{g} / \mathrm{mL}$ and $150 \mu \mathrm{g} / \mathrm{mL}$. These solutions were injected into the chromatographic system, and the resulting areas of the peaks were plotted against concentration for the calibration curve.

\subsection{Total Phenol Determination}

The total phenolic content of sea buckthorn berries was determined spectrophotometrically at $765 \mathrm{~nm}$ following the Folin-Ciocalteu method as described by Singleton et al. [32]. A standard calibration curve was plotted by using gallic acid (Merck, Germany) in the concentration range 1-500 $\mathrm{mg} / \mathrm{L}$. The results were expressed as milligrams of gallic acid equivalent (GAE) per $100 \mathrm{~g}$ of fresh berries.

\subsection{Extraction and Determination of Individual Phenolics}

The phenolic acids in sea buckthorn berries were determined following the procedure described by Rodriguez-Delgado et al. [33]. From $200 \mathrm{~g}$ of fragmented sample, ca. $50 \mathrm{~g}$ of sample (per replicate) was transferred to a centrifuge tube, mixed homogeneously, then diluted 1:1 with distilled water, and centrifuged at $15,000 \times g$ for $15 \mathrm{~min}$. The supernatant was passed through a $0.45 \mu \mathrm{m}$ Millex-HV hydrophilic Polyvinylidene fluoride PVDF membrane filter, and then injected into the HPLC system (gradient). The chromatographic separation in the Agilent 1100 series HPLC took place in a DAD detector (Agilent, Santa Clara, CA, USA) with a $250 \mathrm{~mm} \times 4.6 \mathrm{~mm}, 4 \mathrm{~m}$ Octadecylsilyl Groups (ODS) column (HiChrom, Reading, UK). The following solvents in water with a flow rate of $1 \mathrm{~mL} / \mathrm{min}$ and $20 \mu \mathrm{L}$ injection volume were used for spectral measurements taken at both $254 \mathrm{~nm}$ and $280 \mathrm{~nm}$ as the mobile phase: solvent A, methanol-acetic acid-water (10:2:88); solvent B, methanol-acetic acid-water (90:2:8).

\subsection{Determination of Trolox Equivalent Antioxidant Capacity (TEAC)}

For total antioxidant determination, the Trolox equivalent antioxidant capacity (TEAC) assay was used. TEAC was determined with ABTS (2,2'-azino-bis-3-ethylbenzo-thiazoline6-sulfonic acid) by dissolving in an acetate buffer using potassium persulfate [34]. For longer stability, the mixture was diluted with $20 \mathrm{mM}$ sodium acetate buffer in an acidic $\mathrm{pH}$ of 4.5 and read at $734 \mathrm{~nm}$ wavelength, $0.700 \pm 0.01$. For the spectrometric assay, $3 \mathrm{dm}^{3}$ ABTS+ was mixed with a $20 \mathrm{dm}^{3}$ fruit extract sample and incubated for $10 \mathrm{~min}$, and then absorbance was detected at $734 \mathrm{~nm}$. The results were expressed as mmol Trolox equivalent/100 $\mathrm{g}$ fresh weight (FW).

\subsection{FRAP (Ferric Reducing Antioxidant Power) Assay}

According to the methods of Benzie and Strain [35], the FRAP assay was used. The assay was conducted using three aqueous stock solutions containing $0.1 \mathrm{~mol} / \mathrm{L}$ acetate buffer (pH 3.6), 10 mmol/L TPTZ (2,4,6-tris(2-pyridyl)-1,3,5-triazine) acidified with concentrated hydrochloric acid, and $20 \mathrm{mmol} / \mathrm{L}$ ferric chloride. These solutions were prepared 
and stored in the dark under refrigeration. Stock solutions were combined $(10: 1: 1, v / v / v)$ to form the FRAP reagent just prior to analysis. For each assay, laboratory duplicates from each replicate plus $2.97 \mathrm{~mL}$ of FRAP reagent and $30 \mathrm{~mL}$ of sample extract were mixed. After $30 \mathrm{~min}$, the absorbance of the reaction mixture at $593 \mathrm{~nm}$ was determined on a spectrophotometer. The results were expressed as mmol Trolox/100 $\mathrm{g}$ FW.

\subsection{Crude Lipid Extraction}

Crude lipid was extracted from $20 \mathrm{~g}$ of sea buckthorn berries per genotype using hexane solvent in a Soxhlet apparatus for 6-7 h after solvent was removed by a rotary evaporator (Heidolph, Hei-VAP Value; pressure $<10 \mathrm{mbar}$, and temperature $40^{\circ} \mathrm{C}$ ). Berries were placed in a porous thimble of a Soxhlet extractor with a cotton plug at its mouth, and the thimble was placed in an extraction chamber which was suspended in a previously weighed flask containing methanol, methanol-chloroform, or petroleum ether. The whole assembly was adjusted, and the flask was heated using a heating metal for 8-10 h to extract lipid. After the extraction, the thimble was removed from the Soxhlet apparatus and the solvent was removed under reduced pressure to afford lipid. Furthermore, the flask containing lipid was placed in the oven at $100{ }^{\circ} \mathrm{C}$ for $30 \mathrm{~min}$ to remove residual solvent, cooled in a desiccator, and weighed. The amount of lipid was calculated and expressed as the percentage crude lipid content [36].

\subsection{Determination of Fatty Acid Composition by Gas Chromatography}

Methanolic $\mathrm{HCl}$ was prepared by the gradual addition of $20 \mathrm{~mL}$ of acetyl chloride to $100 \mathrm{~mL}$ of cold methanol. Fatty acid methyl esters (FAMEs) were prepared from total lipid extracts of sea buckthorn berry tissues by adding $1 \mathrm{~mL}$ of methanolic $\mathrm{HCl}$ to $1 \mathrm{mg}$ of total lipid and incubating for $1 \mathrm{~h}$ at $80^{\circ} \mathrm{C}$. The methylation was quenched by the addition of $1 \mathrm{~mL}$ of $0.9 \%$ aqueous sodium chloride, and the FAMEs were extracted twice with $2 \mathrm{~mL}$ of hexane. The resulting FAME extract was evaporated under nitrogen and resuspended in isooctane for GC/MS analysis. GC/MS analysis of FAMEs was performed on an Agilent $6890 \mathrm{~N}$ gas chromatograph with an Agilent 5975 B Inert XL mass selective detector. Chromatographic separation was achieved using a DB-23 capillary column (J\&W Scientific, Folsom CA; $30 \mathrm{~m} \times 250 \mu \mathrm{m} \times 0.25 \mu \mathrm{m})$ with the following temperature program: initial temperature $90{ }^{\circ} \mathrm{C}$, raised at $10{ }^{\circ} \mathrm{C} / \mathrm{min}$ to $165^{\circ} \mathrm{C}$, held for $5 \mathrm{~min}$, and then raised at $3{ }^{\circ} \mathrm{C} / \mathrm{min}$ to a final temperature of $230{ }^{\circ} \mathrm{C}$. The inlet was operated in splitless mode at a temperature of $290^{\circ} \mathrm{C}$, with helium as the carrier gas at constant flow of $1.2 \mathrm{~mL} / \mathrm{min}$. The transfer line temperature was $250{ }^{\circ} \mathrm{C}$, and the MS ion source and quadrupole temperatures were set to $230{ }^{\circ} \mathrm{C}$ and $150{ }^{\circ} \mathrm{C}$, respectively. MS detection was carried out in electron impact (EI) ionization mode, scanning all masses from 30-350 amu. Peaks were identified on the basis of mass spectral comparison with the NIST05 MS library in combination with retention time, matching to external FAME standards [37].

\subsection{Statistical Analysis}

Differences among genotypes were determined through analysis of variance (ANOVA) using the SPSS 22 software program, and results were evaluated with the least significant difference (LSD) method at $p<0.05$. In Section 3 , mean values and standard deviations are given $(\bar{x} \pm S D)$.

\section{Results and Discussion}

\section{Agro-Morphological Traits}

The 100-berry weight, berry shape, berry skin color, ripening time, growth habit, presence of thorns, and leaf area of 10 genotypes are shown in Table 1. Statistically significant differences among genotypes for 100-berry weight $(p<0.05)$ were determined. The genotypes exhibited 100-berry weight in a range between $13.85 \mathrm{~g}$ (S-4) and $27.87 \mathrm{~g}$ (S-8) indicating a twofold difference among S-4 and S-8 genotypes. Most of the genotypes (six 
genotypes) revealed oblong fruit shape, followed by elliptical (two genotypes) and oblate berry shape (two genotypes) (Table 1).

Table 1. Means and SD values of agro-morphological characteristics of the 10 sea buckthorn genotypes.

\begin{tabular}{cccccccc}
\hline Genotypes & $\begin{array}{c}\text { 100-Berry } \\
\text { Weight } \mathbf{( g )}\end{array}$ & Berry Shape & $\begin{array}{c}\text { Berry Skin } \\
\text { Color }\end{array}$ & $\begin{array}{c}\text { Ripening } \\
\text { Time }\end{array}$ & $\begin{array}{c}\text { Growth } \\
\text { Habit }\end{array}$ & $\begin{array}{c}\text { Thorns } \\
\text { Leaf Area } \\
\mathbf{( c m}^{\mathbf{2}} \mathbf{)}\end{array}$ \\
\hline S-1 & $17.11 \pm 0.8^{\mathrm{d}}$ & Elliptic & Light orange & 23 September & Shrub & Few & $2.56 \pm 0.2^{\mathrm{c}}$ \\
S-2 & $21.34 \pm 0.9^{\mathrm{bc}}$ & Oblong & Orange & 2 October & Tree & Few & $3.40 \pm 0.2^{\mathrm{ab}}$ \\
S-3 & $18.56 \pm 0.8^{\mathrm{cd}}$ & Oblong & Light orange & 27 September & Tree & Medium & $2.89 \pm 0.1^{\mathrm{bc}}$ \\
S-4 & $13.85 \pm 0.6^{\mathrm{e}}$ & Elliptic & Yellow & 30 September & Shrub & Few & $3.98 \pm 0.2^{\mathrm{ab}}$ \\
S-5 & $14.47 \pm 0.5^{\mathrm{de}}$ & Ovate & Light orange & 4 October & Shrub & Few & $4.02 \pm 0.3^{\mathrm{ab}}$ \\
S-6 & $25.11 \pm 0.7^{\mathrm{b}}$ & Oblong & Dark orange & 7 October & Tree & Medium & $4.22 \pm 0.3^{\mathrm{a}}$ \\
S-7 & $20.38 \pm 0.9^{\mathrm{c}}$ & Oblong & Orange & 30 September & Tree & Medium & $3.70 \pm 0.2^{\mathrm{ab}}$ \\
S-8 & $27.87 \pm 1.1^{\mathrm{a}}$ & Ovate & Yellow & 1 October & Shrub & Few & $3.23 \pm 0.1^{\mathrm{b}}$ \\
S-9 & $19.79 \pm 0.8^{\mathrm{cd}}$ & Oblong & Light orange & 25 September & Shrub & Few & $3.04 \pm 0.2^{\mathrm{bc}}$ \\
S-10 & $16.50 \pm 1.0^{\mathrm{de}}$ & Oblong & Yellow & 27 September & Tree & Few & $2.96 \pm 0.1^{\mathrm{bc}}$ \\
\hline
\end{tabular}

Different letters in same column indicate significant differences at the 0.05 level.

Four genotypes had light-orange berry skin color, three genotypes had yellow berry skin color, two genotypes had orange berry skin color, and only one genotype had darkorange berry skin color. The ripening time of the 10 genotypes occurred from 23 September (S-1) to 7 October (S-6). Regarding the growth habit, trees and shrubs were represented equally, with five genotypes each. Seven genotypes presented only few thorns per plant, while the remaining genotypes showed medium presence of thorns. Leaf area of the genotypes ranged from $2.56 \mathrm{~cm}^{2}$ (S-1) to $4.22 \mathrm{~cm}^{2}$ (S-6) with statistically significant differences $(p<0.05)$ among the analyzed genotypes.

The results indicate that sea buckthorn genotypes were quite variable in most of the agro-morphological characteristics. In fact, previous studies conducted in different countries also showed great diversity in most of the agro-morphological traits in sea buckthorn. For example, Sezen et al. [38] used 30 female seed-propagated sea buckthorn genotypes to determine their landscape and horticulture value and reported quite variable 100-berry weight that ranged between 15 and $26 \mathrm{~g}$. Zheng et al. [39] used a large number of sea buckthorn cultivars belonging to ssp. mongolica and found 100-berry weight between 37 and $74 \mathrm{~g}$. Zheng et al. [40] reported 100-berry weight between 9 and $20 \mathrm{~g}$ among ssp. sinensis genotypes. In India, 100-berry weight of sea buckthorn genotypes was found to be between $11.53 \mathrm{~g}$ and $18.87 \mathrm{~g}$ [41]. In China, it was reported to vary between 18.5 and $19.5 \mathrm{~g}$ among genotypes belonging to H. rhamnoides and between 19.0 and $20.5 \mathrm{~g}$ among genotypes belonging to $H$. salicifolia [42]. In another study conducted in different valleys in India, diverse 100-berry weight was documented. For example, in Mana valley, they reported average 100-berry weight of $21.25 \mathrm{~g}$, whereas, in Niti valley, the 100-berry weight amounted to $16.73 \mathrm{~g}$ [43]. Li et al. [16] used 78 diverse sea buckthorn accessions and reported 100-berry weight between $10.73 \mathrm{~g}$ (H. rhamnoides ssp. sinensis) and $47.69 \mathrm{~g}$ (H. rhamnoides ssp. mongolica).

Yadav et al. [41] used a number of wild-grown sea buckthorn genotypes in India and found that fruit shape varied from round to ovate, while berry skin color ranged from greenish-yellow to yellow-orange in H. salicifolia accessions. Sezen et al. [38] found that the majority of $H$. rhamnoides genotypes in Coruh valley in Turkey had oblong berry shape while yellow, light-yellow, dark-yellow, yellow-orange, orange, and dark-orange peel colors were present among wild-grown sea buckthorn genotypes. India is one of the richest countries in terms of variability of sea buckthorn's gene pool, and Dhyani et al. [43] found oval, elliptical, round oval/elliptical, and ovate berry shape with diverse berry skin color including orange yellow, orange, reddish yellow, red orange, and orange. Li et al. [16] used 78 diverse sea buckthorn accessions and reported oblong, ovate, and elliptical berry shape. 
Sezen et al. [38] reported early or medium ripening characteristics in sea buckthorn genotypes in Turkey. Singh and Singh [44] also found great variations for this morphological trait in native $H$. salicifolia and H. rhamnoides female plants in Himachal Pradesh. Sezen et al. [38] also reported that most of the sea buckthorn genotypes had a bush growth habit, but the tree growth habit was also evident. This was also strongly supported in a study conducted in India, which revealed that most of the sea buckthorn genotypes had a bush growth habit [41].

Previously, Sezen et al. [38] found that most of the sea buckthorn genotypes had few or medium thorns, and the leaf area of these genotypes was between 1.59 and $4.26 \mathrm{~cm}^{2}$, indicating great variability. In India, leaf area was found to be between 2.28 and $9.35 \mathrm{~cm}^{2}$ among sea buckthorns belonging to different species [41]. Sabir et al. [20] also reported a quite variable number of thorns and leaf sizes among sea buckthorn genotypes grown in Pakistan. The agro-morphological characteristics varied among studies conducted on different continents. These differences could be connected to diverse origins, species, different parts of the fruit analyzed, climatic and growing conditions, etc.

Table 2 shows the results obtained from the juice analyses, including juice yield, vitamin C content, titratable acidity, SSC, and protein and lipid content of the 10 analyzed genotypes. For all researched parameters, statistically significant differences were evident at the 0.05 level.

Table 2. Means and SD values of juice yield, vitamin C, soluble solid content (SSC), titratable acidity, and protein and lipid content in pulps of the 10 sea buckthorn genotypes.

\begin{tabular}{|c|c|c|c|c|c|c|}
\hline Genotypes & Juice Yield (\%) & $\begin{array}{l}\text { Vitamin C } \\
(\mathrm{mg} / 100 \mathrm{~g})\end{array}$ & $\begin{array}{c}\text { Titratable } \\
\text { Acidity (\%) }\end{array}$ & SSC (\%) & Protein (\%) & Lipid (\%) \\
\hline S-1 & $52.25 \pm 2.3^{c}$ & $40.10 \pm 2.4^{h}$ & $3.88 \pm 0.2^{b c}$ & $12.95 \pm 0.6^{\mathrm{cd}}$ & $0.74 \pm 0.2^{b}$ & $5.70 \pm 0.4^{\mathrm{ab}}$ \\
\hline S-2 & $57.15 \pm 2.7^{a}$ & $57.25 \pm 3.9^{c}$ & $3.40 \pm 0.2^{b c}$ & $12.56 \pm 0.5^{\mathrm{de}}$ & $0.66 \pm 0.1^{b c}$ & $5.02 \pm 0.3^{c}$ \\
\hline S-3 & $54.42 \pm 3.9^{b}$ & $44.51 \pm 2.0^{g}$ & $4.01 \pm 0.3^{b}$ & $12.86 \pm 0.7^{\mathrm{cd}}$ & $0.72 \pm 0.2^{b}$ & $5.49 \pm 0.4^{b}$ \\
\hline S-4 & $44.87 \pm 3.1^{\mathrm{g}}$ & $54.33 \pm 3.1^{d}$ & $3.80 \pm 0.1 \mathrm{bc}$ & $14.67 \pm 0.7^{\mathrm{ab}}$ & $0.60 \pm 0.1^{\mathrm{c}}$ & $6.03 \pm 0.5^{a b}$ \\
\hline S-5 & $50.40 \pm 2.9^{d}$ & $37.45 \pm 2.7^{\mathrm{i}}$ & $3.76 \pm 0.2 b c$ & $13.17 \pm 0.5^{\mathrm{cd}}$ & $0.63 \pm 0.1 \mathrm{bc}$ & $5.58 \pm 0.3^{a b}$ \\
\hline S-6 & $48.83 \pm 2.4^{\mathrm{e}}$ & $48.03 \pm 3.3^{\mathrm{f}}$ & $3.14 \pm 0.2^{c}$ & $14.80 \pm 0.6^{\mathrm{a}}$ & $0.83 \pm 0.1^{\mathrm{a}}$ & $6.17 \pm 0.3^{a}$ \\
\hline S-7 & $47.75 \pm 3.2^{\text {ef }}$ & $49.28 \pm 4.6^{\text {ef }}$ & $4.17 \pm 0.3^{\mathrm{ab}}$ & $14.07 \pm 0.5^{b}$ & $0.66 \pm 0.2^{b c}$ & $5.40 \pm 0.2^{b c}$ \\
\hline S-8 & $46.58 \pm 2.7^{\mathrm{f}}$ & $62.85 \pm 5.4^{a}$ & $3.30 \pm 0.2^{b c}$ & $13.90 \pm 0.5^{b c}$ & $0.80 \pm 0.2^{a b}$ & $5.78 \pm 0.4^{a b}$ \\
\hline S-9 & $49.33 \pm 2.5$ ef & $60.14 \pm 4.2^{b}$ & $4.73 \pm 0.3^{\mathrm{a}}$ & $13.45 \pm 0.6^{\mathrm{c}}$ & $0.70 \pm 0.1^{\mathrm{b}}$ & $6.10 \pm 0.3^{a b}$ \\
\hline S-10 & $54.10 \pm 4.0^{b}$ & $50.62 \pm 2.4^{\mathrm{e}}$ & $4.20 \pm 0.1^{\mathrm{ab}}$ & $12.70 \pm 0.4^{\mathrm{d}}$ & $0.72 \pm 20.1^{b}$ & $5.65 \pm 0.3^{a b}$ \\
\hline
\end{tabular}

Different letters in same column indicate significant differences at the 0.05 level.

As shown in Table 2, genotypes S-2, S-3, S-10, S-1, and S-5 had higher values of fruit juice yield, i.e., $57.15 \%, 54.42 \%, 54.10 \%, 52.25 \%$, and $50.40 \%$, respectively. The lowest fruit juice yield was obtained from genotype S-4, which amounted to $44.87 \%$. Sezen et al. [38] reported quite variable berry juice yield among 30 seed-propagated female sea buckthorn genotypes grown in Coruh valley in Turkey, ranging between $37.00 \%$ and $53.60 \%$, indicating similarity with our study. Zheng et al. [39] used a large number of sea buckthorn cultivars belonging to ssp. mongolica and found juice yield between $50.5 \%$ and $59.4 \%$. Zheng et al. [40] reported juice yield between $38.9 \%$ and $62.7 \%$ among ssp. sinensis genotypes. Previous researches showed higher fruit juice yield (60-80\%) among sea buckthorn genotypes and cultivars $[20,41,43,45,46]$ compared to our study. The observed differences could be the result of plant material used (different species, genotypes, accessions, etc.), growing locality, agronomic practices applied, etc.

The vitamin C content of the 10 sea buckthorn genotypes in this study was in the range of $37.45 \mathrm{mg} / 100 \mathrm{~g}(\mathrm{~S}-5)$ to $62.85 \mathrm{mg} / 100 \mathrm{~g}$ (S-8), indicating nearly twofold differences between these two genotypes. Sezen et al. [38] found lower vitamin C content (between 19 and $34 \mathrm{mg}$ per $100 \mathrm{~g}$ ) among sea buckthorn genotypes. Yao et al. [47] studied vitamin C concentrations of 71 Hippophae rhamnoides genotypes and found quite variable vitamin C content ranging from 28 to $201 \mathrm{mg} / 100 \mathrm{~g}$. Jalakas et al. [48] reported vitamin C content to 
vary between 49 and $65 \mathrm{mg}$ per $100 \mathrm{~g}$ among sea buckthorn cultivars. The great variations in the vitamin $C$ content of sea buckthorn genotypes are characteristic for this unique plant species. This trait could also be affected by the genotype, geographical origin, level of maturity of the berries, growing conditions, etc. [40].

The soluble solid content (SSC) and titratable acidity content of the genotypes in this study varied from $12.56 \%$ (S-2) to $14.67 \%$ (S-4) and $3.14 \%$ (S-6) to $4.73 \%$ (S-9), respectively. Genotypes greatly differed from each other for SSC and titratable acidity content at the 0.05 level (Table 2). Sezen et al. [38] reported SSC and titratable acidity among sea buckthorn (H. rhamnoides) genotypes to be $10.65-14.60 \%$ and $2.75-5.02 \%$, respectively which is in accordance with our results. Sea buckthorn berries are considered highly acidic fruits. In Finland, the SSC content of sea buckthorn was reported to be between $7.4 \%$ and $12.6 \%$ [29]. Kuhkheil et al. [49] found that the content of vitamin C and SSC were the main variables in chemical constituents for the effective detection of original wild populations of sea buckthorn (Hippophae rhamnoides L.) in central Alborz Mountains in Iran. They reported the lowest SSC of $8.60 \%$ and average SSC content between $17 \%$ and $20 \%$ in different years by using a large number of populations. Zheng et al. [39] used a large number of sea buckthorn cultivars belonging to ssp. mongolica and found SSC and acidity to be 7.40-9.00\% and $2.90-4.99 \%$, respectively. Zheng et al. [40] found SSC to be between $7.3 \%$ and $21.8 \%$ among ssp. sinensis genotypes.

The protein and lipid content of sea buckthorn genotypes is given in Table 2. The genotypes exhibited statistically significant differences for both analyzed parameters at the 0.05 level. Protein and lipid content was $0.60 \%$ (S-4) to $0.80 \%$ (S-8) and 5.02\% (S-2) to $6.17 \%$ (S-6), respectively. These results indicate that sea buckthorn berries are a rich source of proteins and lipids (Table 2). Criste et al. [25] analyzed four varieties of sea buckthorn (H. rhamnoides) in Romania and found protein content ranging between $0.72 \%$ in the Carmen variety and $0.86 \%$ in the SF- 6 variety. These results agree with our findings on protein content. One of the most important properties of sea buckthorn berries is its lipid content in the mesocarp section, as well as in the seeds [49-51]. The lipid content of whole berries can vary considerably with the variety and other factors. Criste et al. [25] investigated four varieties of sea buckthorn (H. rhamnoides) in Romania and reported lipid content of berries (pulp) ranging between $4.61 \%$ and $5.71 \%$. The lipid content of the mesocarp (pulp) of sea buckthorn berries is mainly determined by the used genotype, as well as by the environmental conditions. Previous studies also reflected a genotypic effect on the lipid content of fresh berries of Hippophae spp.; the reported lipid percentage ranged from $1.4 \%$ in ssp. sinensis from China up to $13.7 \%$ in ssp. turkestanica from the Western Pamirs [52]. The specific sugar content of genotypes is given in Table 3 . The genotypes contained mainly glucose $(0.14-0.71 \%)$ and fructose $(0.10-0.59 \%)$, while a few genotypes contained negligible sucrose content (Table 3).

Table 3. Means and SD values of the contents of specific sugars of the 10 sea buckthorn genotypes.

\begin{tabular}{cccc}
\hline Genotypes & Glucose (\%) & Frucose (\%) & Sucrose (\%) \\
\hline S-1 & $0.39 \pm 0.1^{\mathrm{d}}$ & $0.25 \pm 0.1^{\mathrm{c}}$ & nd \\
S-2 & $0.14 \pm 0.0^{\mathrm{fg}}$ & $0.10 \pm 0.0^{\mathrm{d}}$ & nd \\
S-3 & $0.30 \pm 0.1^{\mathrm{e}}$ & $0.19 \pm 0.0^{\mathrm{cd}}$ & nd \\
S-4 & $0.68 \pm 0.2^{\mathrm{ab}}$ & $0.52 \pm 0.1^{\mathrm{ab}}$ & 0.07 \\
S-5 & $0.50 \pm 0.2^{\mathrm{c}}$ & $0.30 \pm 0.1^{\mathrm{bc}}$ & nd \\
S-6 & $0.71 \pm 0.2^{\mathrm{a}}$ & $0.59 \pm 0.1^{\mathrm{a}}$ & 0.09 \\
S-7 & $0.64 \pm 0.1^{\mathrm{ab}}$ & $0.48 \pm 0.1^{\mathrm{ab}}$ & nd \\
S-8 & $0.60 \pm 0.1^{\mathrm{b}}$ & $0.40 \pm 0.1^{\mathrm{b}}$ & 0.04 \\
S-9 & $0.55 \pm 0.1^{\mathrm{bc}}$ & $0.34 \pm 0.1^{\mathrm{bc}}$ & nd \\
S-10 & $0.22 \pm 0.0^{\mathrm{f}}$ & $0.15 \pm 0.0^{\mathrm{cd}}$ & nd \\
\hline
\end{tabular}

Different letters in same column indicate significant differences at the 0.05 level; nd, not detected. 
We found statistically significant differences in fructose and glucose content among the 10 sea buckthorn genotypes. Previously, Yang [53] studied specific sugars in sea buckthorn berries and reported glucose and fructose as the main sugars in berries for all three major subspecies (H. rhamnoides ssp. sinensis, ssp. rhamnoides, and ssp. mongolica). Criste et al. [25] reported glucose and fructose as the main specific sugars in four sea buckthorn cultivars belonging to $H$. rhamnoides in Romania and reported fructose and glucose content of 0.18 $1.10 \%$ and $0.17-0.46 \%$, respectively. They also found that only one cultivar contained a negligible amount of sucrose, determining at the same time higher glucose than fructose content, similarly to our findings. Glucose content in our research was also similar to the findings of Yang [53] in all samples of H. rhamnoides. In another study, Yang et al. [54] found fructose and glucose to range from $0.6 \%$ in ssp. rhamnoides to $24.2 \%$ in berries of ssp. sinensis. Zheng et al. $[39,40]$ indicated glucose and fructose as the main sugars in sea buckthorn berries, suggesting that both sugars levels are affected by the cultivars.

In Table 4 , the total phenolic content, total anthocyanins, and antioxidant capacity in berries from the 10 sea buckthorn genotypes are shown. As indicated in Table 4, the differences in all analyzed parameters among genotypes were statistically significant $(p<0.05)$.

Table 4. Means and SD values of total phenolic content, total anthocyanins, and antioxidant capacity (ferric reducing antioxidant power (FRAP) and Trolox equivalent antioxidant capacity (TEAC) assays) of the 10 sea buckthorn genotypes.

\begin{tabular}{ccccc}
\hline Genotypes & $\begin{array}{c}\text { Total Phenolic } \\
\text { Content } \mathbf{( m g} \\
\text { GAE/100 g) }\end{array}$ & $\begin{array}{c}\text { Total } \\
\text { Anthocyanin } \\
(\mathbf{m g} / \mathbf{L})\end{array}$ & $\begin{array}{c}\text { FRAP (mg Trolox } \\
\text { Equivalent/100 g } \\
\text { FW) }\end{array}$ & $\begin{array}{c}\text { TEAC (mg Trolox } \\
\text { Equivalent/100 g } \\
\text { FW) }\end{array}$ \\
\hline S-1 & $486 \pm 24^{\mathrm{f}}$ & $19.4 \pm 0.4^{\mathrm{e}}$ & $0.54 \pm 0.1^{\mathrm{c}}$ & $2.04 \pm 0.2^{\mathrm{d}}$ \\
S-2 & $522 \pm 33^{\mathrm{d}}$ & $31.1 \pm 0.7^{\mathrm{b}}$ & $1.06 \pm 0.2^{\mathrm{b}}$ & $2.11 \pm 0.2^{\mathrm{cd}}$ \\
S-3 & $450 \pm 18^{\mathrm{hi}}$ & $22.5 \pm 0.6^{\mathrm{c}}$ & $0.77 \pm 0.1^{\mathrm{bc}}$ & $1.89 \pm 0.1^{\mathrm{de}}$ \\
S-4 & $412 \pm 14^{\mathrm{i}}$ & $11.2 \pm 0.4^{\mathrm{f}}$ & $0.45 \pm 0.1^{\mathrm{cd}}$ & $1.71 \pm 0.1^{\mathrm{e}}$ \\
S-5 & $587 \pm 20^{\mathrm{c}}$ & $20.4 \pm 0.5^{\mathrm{d}}$ & $1.22 \pm 0.2^{\mathrm{ab}}$ & $2.34 \pm 0.2^{\mathrm{c}}$ \\
S-6 & $495 \pm 22^{\mathrm{ef}}$ & $38.7 \pm 0.8^{\mathrm{a}}$ & $0.87 \pm 0.2^{\mathrm{bc}}$ & $1.67 \pm 0.1^{\mathrm{e}}$ \\
S-7 & $507 \pm 19^{\mathrm{e}}$ & $29.4 \pm 0.3^{\mathrm{c}}$ & $1.01 \pm 0.2^{\mathrm{bc}}$ & $2.28 \pm 0.2^{\mathrm{cd}}$ \\
S-8 & $622 \pm 30^{\mathrm{a}}$ & $11.4 \pm 0.1^{\mathrm{f}}$ & $1.48 \pm 0.2^{\mathrm{a}}$ & $2.93 \pm 0.2^{\mathrm{a}}$ \\
S-9 & $604 \pm 27^{\mathrm{b}}$ & $21.6 \pm 0.3^{\mathrm{cd}}$ & $1.34 \pm 0.2^{\mathrm{ab}}$ & $2.78 \pm 0.2^{\mathrm{b}}$ \\
S-10 & $461 \pm 19^{\mathrm{g}}$ & $9.1 \pm 0.2^{\mathrm{g}}$ & $0.37 \pm 0.1^{\mathrm{cd}}$ & $1.58 \pm 0.1^{\text {ef }}$ \\
\hline
\end{tabular}

Different letters in same column indicate significant differences at the 0.05 level; GAE, gallic acid equivalent; FW fresh weight.

A high genotypic variation in terms of total phenolic content was observed (412$622 \mathrm{mg} \mathrm{GAE} / 100 \mathrm{~g} \mathrm{FW})$. The highest total phenolic content was observed in genotype S-8 (622 mg GAE/100 $\mathrm{g} \mathrm{FW),} \mathrm{followed} \mathrm{by} \mathrm{the} \mathrm{S-5} \mathrm{genotype} \mathrm{(587} \mathrm{mg} \mathrm{GAE/100} \mathrm{g} \mathrm{FW),} \mathrm{while} \mathrm{the}$ lowest value was recorded in genotype S-4 (412 mg GAE/100 g FW; Table 4).

Total phenolic content was previously reported to be quite variable among sea buckthorn cultivars and genotypes grown in different agro-climatic conditions in the world. Saeidi et al. [55] reported $247 \mathrm{mg}$ GAE/100 g FW of total phenolic content in wild-grown H. rhamnoides ssp. rhamnoides, indicating lower values than those recorded in our samples. However, Rop et al. [56] and Crieste et al. [25] found total phenolic content in four sea buckthorn cultivars grown in Czech Republic and Romania to range from 862-1417 mg GAE/100 g and 1012-1866 mg GAE/100 g FW, values higher than those recorded in our study. Bittová et al. [57] also reported higher total phenolic content (i.e., between 1070 and $1730 \mathrm{mg}$ GAE/100 g) in berries of sea buckthorn cultivars. All of the abovementioned studies revealed significant differences existing among sea buckthorn cultivars in terms of total phenolic content. Di Mauro et al. [58] reported that the polyphenolic profile in olive is cultivar-dependent. The local sea buckthorn genotypes were characterized by markedly higher contents of total polyphenols compared to blackberry (262 mg/100 g), blueberry (300 mg/100 g), raspberry (322 mg/100 g), strawberry (323 mg/100 g), and blackcurrant 
(434 mg/100 g) [59]. The World Health Organization (WHO) recommendation to increase consumption of fruit, vegetables, and fiber is a key lifestyle change that could help to reduce the risk of noncommunicable diseases (NCDs) [60]. Although deficiencies in polyphenol intake do not result in specific deficiency diseases, adequate intake of polyphenols could confer health benefits, especially with regard to chronic diseases. Tea, cocoa, fruits, and berries, as well as vegetables, are rich in polyphenols [61].

Genotype S-6 with dark-orange color had the highest total anthocyanin content in berries $(38.7 \mathrm{mg} / \mathrm{L})$, while yellow berry genotypes such as S-4, S-8, and S-10 genotypes had the lowest total anthocyanin content, i.e., $11.2 \mathrm{mg} / \mathrm{L}, 11.4 \mathrm{mg} / \mathrm{L}$, and $9.3 \mathrm{mg} / \mathrm{L}$, respectively (Table 4). The differences in total anthocyanins among genotypes were found to be statistically significant at $p<0.05$ (Table 4). Tiitinen et al. [29] previously studied a number of sea buckthorn genotypes in Finland and reported the total anthocyanin content of sea buckthorn berries to range from 7 to $38 \mathrm{mg} / \mathrm{L}$, demonstrating similarities with our study. Sezen et al. [38] also found that relatively dark-orange sea buckthorn berries contain more anthocyanin than yellow and light-yellow sea buckthorn berries. Sabir et al. [20] studied sea buckthorn genotypes in Pakistan and reported anthocyanin content ranging between 0.5 and $25 \mathrm{mg} / \mathrm{L}$, which in accordance with our results.

We found statistically significant differences $(p<0.05)$ among genotypes for antioxidant capacity by using FRAP and TEAC assays. Genotype S- 8 showed the highest antioxidant capacity in both methods as $2.93 \mathrm{mmol}$ Trolox equivalent/100 $\mathrm{g}$ in the TEAC assay and $1.48 \mathrm{mmol}$ Trolox equivalent/100 $\mathrm{g}$ in the FRAP assay (Table 4). In addition, the genotypes that had the highest total phenolic content also showed the highest antioxidant activity in both assays. The FRAP, TEAC, and TPC (total phenolic content) results showed a close relationship, indicating that antioxidant capacity is attributable to the wide range of polyphenols present in sea buckthorn berry skin and flesh. Chen et al. [62] also reported that antioxidant activity in sea buckthorn berries followed the same trend as the concentrations of total phenolics. On the basis of these findings, it can be concluded that differences among the phenolic profiles and antioxidant capacities of sea buckthorn berries significantly depend on the genotype because all plants in our study were growing in similar environmental conditions, receiving similar sun exposure and temperature levels. Makovics-Zsohar et al. [63] investigated six sea buckthorn genotypes in Hungary and revealed a nearly threefold difference between the lowest and highest antioxidant capacities of the tested genotypes. They reported TEAC values that ranged between 1.76 and $3.13 \mathrm{mmol}$ Trolox equivalent/100 $\mathrm{g}$ fresh weight and FRAP values that ranged between 0.45 and $1.80 \mathrm{mmol}$ AA equivalent/100 g. They also found that Hippophae rhamnoides berries possess in vitro antioxidant activity, strongly determined by the genotype as well as by the harvest time. Criste et al. [25] also reported that the antioxidant capacity of four sea buckthorn genotypes was quite variable among genotypes, and all genotypes had relatively high antioxidant capacity determined by 2.2-diphenyl-1-picrylhdrazyl (DPPH) and TEAC assays.

The fatty acid content of fruits of the 10 sea buckthorn genotypes is given in Table 5 . It is obvious that the genotype strongly influenced fatty acid content, and that there were statistically significant differences among genotypes $(p<0.05)$ for individual fatty acids, except stearic acid (Table 5).

Linoleic acid was the main fatty acid in the pulp of sea buckthorn genotypes and varied among genotypes from $24.11 \%$ to $36.37 \%$. This fatty acid was followed by palmitoleic acid (18.13-26.44\%) and palmitic acid (15.40-21.20\%). The content of linolenic and stearic acid was determined to be lower than that of the abovementioned fatty acids and ranged from $3.88-7.02 \%$ and $1.80-3.23 \%$, respectively (Table 5). Fatty acids in sea buckthorn berries (pulp) are very important from a nutritive point of view because sea buckthorn berries are edible when ripe, and it is clear that sea buckthorn berries are a valuable source of some biologically active compounds, including antioxidants and fatty acids. Saeidi et al. [55] found that berries of $H$. rhamnoides grown in Iran include linoleic $(34.2 \%)$, palmitoleic $(21.37 \%)$, palmitic $(17.2 \%)$, oleic $(12 \%)$, linolenic $(5.37 \%)$, and stearic acid $(1.67 \%)$ as dominant fatty 
acids. It is well documented that, among fruits, macadamia and sea buckthorn are high in concentration of palmitoleic acid [64]. Yang and Kallio [52] also found that sea buckthorn fruit (mesocarp or pulp) exhibits a high content of palmitoleic acid. Regarding fatty acid diversity and content, our results are in accordance with the abovementioned studies. The differences between our results and other studies could be explained by genotype, cultivar used, growing and geographical conditions, and environmental factors [65].

Table 5. Means and SD values of fatty acid content in the pulp of the 10 sea buckthorn genotypes (\%).

\begin{tabular}{|c|c|c|c|c|c|c|}
\hline Genotypes & Linoleic Acid & Palmitoleic Acid & Palmitic Acid & Oleic Acid & Linolenic Acid & Stearic Acid \\
\hline S-1 & $36.37 \pm 1.2^{\mathrm{a}}$ & $18.13 \pm 0.7^{\mathrm{e}}$ & $17.07 \pm 0.5^{\mathrm{c}}$ & $9.84 \pm 0.2^{\mathrm{c}}$ & $3.88 \pm 0.2^{b}$ & $1.88 \pm 0.1 \mathrm{NS}$ \\
\hline S-2 & $25.56 \pm 0.9 \mathrm{de}$ & $23.42 \pm 0.9 \mathrm{bc}$ & $19.04 \pm 0.7^{b}$ & $10.87 \pm 0.3^{b c}$ & $5.15 \pm 0.3^{\mathrm{ab}}$ & $2.21 \pm 0.1$ \\
\hline S-3 & $27.43 \pm 1.1^{\mathrm{d}}$ & $20.02 \pm 0.5^{\mathrm{d}}$ & $15.40 \pm 0.4^{\mathrm{d}}$ & $15.40 \pm 0.3^{\mathrm{a}}$ & $4.24 \pm 0.2^{\mathrm{ab}}$ & $1.97 \pm 0.1$ \\
\hline S-4 & $30.02 \pm 1.3^{c}$ & $19.00 \pm 0.5^{\mathrm{de}}$ & $21.01 \pm 0.3^{\mathrm{ab}}$ & $10.36 \pm 0.2 \mathrm{bc}$ & $4.78 \pm 0.2^{\mathrm{ab}}$ & $2.30 \pm 0.2$ \\
\hline S-5 & $24.11 \pm 1.1^{\mathrm{e}}$ & $24.77 \pm 0.8^{b}$ & $20.40 \pm 0.5^{a b}$ & $9.23 \pm 0.3^{c}$ & $6.44 \pm 0.3^{\mathrm{ab}}$ & $2.44 \pm 0.1$ \\
\hline S-6 & $24.97 \pm 0.8^{\mathrm{e}}$ & $21.56 \pm 1.0^{\mathrm{c}}$ & $20.84 \pm 0.4^{\mathrm{ab}}$ & $13.12 \pm 0.2^{b}$ & $6.02 \pm 0.4^{\mathrm{ab}}$ & $2.27 \pm 0.2$ \\
\hline S-7 & $29.27 \pm 1.4^{b c}$ & $20.75 \pm 0.7^{\mathrm{cd}}$ & $18.85 \pm 0.3^{b c}$ & $14.56 \pm 0.4^{\mathrm{ab}}$ & $3.95 \pm 0.3^{b}$ & $2.04 \pm 0.1$ \\
\hline S-8 & $24.88 \pm 1.2^{\mathrm{de}}$ & $26.44 \pm 1.1^{\mathrm{a}}$ & $21.20 \pm 0.5^{\mathrm{a}}$ & $13.87 \pm 0.2^{a b}$ & $5.80 \pm 0.3^{\mathrm{ab}}$ & $2.15 \pm 0.1$ \\
\hline S-9 & $32.11 \pm 1.4^{\mathrm{ab}}$ & $19.68 \pm 0.7 \mathrm{de}$ & $18.38 \pm 0.2^{b c}$ & $11.25 \pm 0.4^{b c}$ & $6.67 \pm 0.4^{\mathrm{ab}}$ & $1.80 \pm 0.1$ \\
\hline S-10 & $33.37 \pm 1.5^{b}$ & $18.47 \pm 0.9^{\mathrm{e}}$ & $19.80 \pm 0.6^{a b}$ & $9.44 \pm 0.3^{c}$ & $7.02 \pm 0.4^{\mathrm{a}}$ & $3.23 \pm 0.2$ \\
\hline
\end{tabular}

Different letters in same column indicate significant differences at the 0.05 level; NS, nonsignificant.

Major individual phenolic acids are shown in Table 6. As can be seen, major phenolic acids in pulp of berries belonging to the 10 analyzed sea buckthorn genotypes were gallic acid (5.43-17.12 mg/100 g), followed by quercetin (2.87-11.47 mg/100 g), rutin (2.87-11.47 mg/100 g), quercitrin (2.44-6.57 mg/100 g), luteolin (0.96-5.12 mg/100 g), and kaemferol (0.44-1.29 mg/100 g). Among all sea buckthorn genotypes, significant differences were recorded in phenolic acids at the 0.05 level (Table 6). Criste et al. [25] reported that gallic acid was the main phenolic acid in sea buckthorn pulp belonging to four cultivars, with concentrations varying from 6.51 to $19.37 \mathrm{mg} / 100 \mathrm{~g}$, thus indicating similarities with our findings. They also reported rutin and quercetin to be the major phenolic acids in sea buckthorn berries. Previously, gallic acid, rutin, and quercetin were reported as main phenolic acids in sea buckthorn berries [64]. Bittova et al. [57] also reported that the main compounds identified in sea buckthorn berries were gallic acid, $p$-coumaric acid, ferulic acid, rutin, and quercitrin

Table 6. Means and SD values of the contents of major individual phenolics in the pulp of the 10 sea buckthorn genotypes (mg/100 g).

\begin{tabular}{|c|c|c|c|c|c|c|}
\hline Genotypes & Gallic Acid & Quercetin & Rutin & Quercitrin & Luteolin & Kaempferol \\
\hline S-1 & $7.44 \pm 0.5^{\mathrm{cd}}$ & $4.42 \pm 0.4^{\mathrm{cd}}$ & $3.86 \pm 0.5^{\mathrm{d}}$ & $2.44 \pm 0.3^{c}$ & $2.44 \pm 0.2^{b}$ & $0.55 \pm 0.1^{b c}$ \\
\hline $\mathrm{S}-2$ & $11.47 \pm 0.6^{b c}$ & $8.45 \pm 0.7^{b}$ & $8.82 \pm 0.8^{a b}$ & $3.66 \pm 0.2^{b c}$ & $2.11 \pm 0.2^{b c}$ & $1.22 \pm 0.2^{\mathrm{a}}$ \\
\hline S-3 & $8.23 \pm 0.6^{\mathrm{cd}}$ & $3.50 \pm 0.4^{\mathrm{cd}}$ & $9.11 \pm 0.6^{\mathrm{ab}}$ & $3.11 \pm 0.3^{b c}$ & $0.96 \pm 0.1^{\mathrm{c}}$ & $0.44 \pm 0.1^{\mathrm{c}}$ \\
\hline S-4 & $6.64 \pm 0.5^{\mathrm{cd}}$ & $2.87 \pm 0.3^{\mathrm{d}}$ & $10.24 \pm 1.0^{\mathrm{ab}}$ & $2.76 \pm 0.3^{c}$ & $1.89 \pm 0.1 \mathrm{bc}$ & $1.15 \pm 0.2^{\mathrm{ab}}$ \\
\hline S-5 & $13.61 \pm 1.0^{\mathrm{b}}$ & $7.56 \pm 0.6^{b c}$ & $8.62 \pm 0.9^{b}$ & $3.03 \pm 0.2^{b}$ & $2.98 \pm 0.2^{\mathrm{ab}}$ & $0.82 \pm 0.1^{b}$ \\
\hline S-6 & $11.10 \pm 1.1^{b c}$ & $9.16 \pm 0.8^{a b}$ & $6.45 \pm 0.5^{b c}$ & $4.30 \pm 0.3^{\mathrm{ab}}$ & $5.12 \pm 0.3^{\mathrm{a}}$ & $1.04 \pm 0.1^{\mathrm{ab}}$ \\
\hline S-7 & $9.56 \pm 0.4^{\mathrm{c}}$ & $5.33 \pm 0.5^{c}$ & $7.24 \pm 0.7^{b c}$ & $4.11 \pm 0.2^{\mathrm{ab}}$ & $4.04 \pm 0.3^{\mathrm{ab}}$ & $0.70 \pm 0.1^{b c}$ \\
\hline S-8 & $17.12 \pm 1.4^{\mathrm{a}}$ & $10.64 \pm 1.0^{\mathrm{ab}}$ & $11.17 \pm 0.8^{\mathrm{a}}$ & $6.57 \pm 0.5^{\mathrm{a}}$ & $3.56 \pm 0.3^{\mathrm{ab}}$ & $0.90 \pm 0.1^{\mathrm{ab}}$ \\
\hline S-9 & $15.40 \pm 1.3^{\mathrm{ab}}$ & $11.47 \pm 1.3^{a}$ & $9.86 \pm 1.0^{\mathrm{ab}}$ & $4.77 \pm 0.7^{\mathrm{ab}}$ & $3.98 \pm 0.2^{\mathrm{ab}}$ & $1.29 \pm 0.2^{\mathrm{ab}}$ \\
\hline S-10 & $5.43 \pm 0.5^{\mathrm{d}}$ & $3.04 \pm 0.3^{\mathrm{cd}}$ & $6.06 \pm 0.6^{c}$ & $2.95 \pm 0.3^{b c}$ & $1.44 \pm 0.2^{b c}$ & $0.62 \pm 0.1 \mathrm{bc}$ \\
\hline
\end{tabular}




\section{Conclusions}

The main results of this study encompassing 10 sea buckthorn genotypes from eastern Turkey displayed important nutritional and bioactive compounds in the sea buckthorn berries. The attested variability among genotypes in terms of physicochemical profiles and horticultural characteristics also showed their potential value for further breeding programs targeting different breeding purposes. The results also indicated the potential use of berries in bio-industrial applications, which remains unexplored so far. Easy propagation and production of this unique fruit species alongside the sustainable harvest of wild-grown plants can contribute to the local economies and have a significant effect on socioeconomic and environmental balance.

Author Contributions: Conceptualization, S.E. and G.I.; data curation, S.E., G.I., and M.G.; formal analysis, S.E., G.I., and M.G.; methodology, S.E. and M.G.; project administration, S.E.; visualization, V.Ž. and S.E.; writing-original draft, K.K., A.V., V.Ž., and S.E.; writing-review and editing, K.K., A.V., and S.E. All authors read and agreed to the published version of the manuscript.

Funding: The authors received no financial support for the research, authorship, and/or publication of this article.

Institutional Review Board Statement: Not applicable.

Informed Consent Statement: Not applicable.

Data Availability Statement: All new research data were presented in this contribution.

Conflicts of Interest: The authors declare that they have no conflict of interest.

\section{References}

1. Colak, A.M.; Okatan, V.; Polat, M.; Guclu, S.F. Different harvest times affect market quality of Lycium barbarum L. berries. Turk. J. Agric. For. 2019, 43, 326-333. [CrossRef]

2. Ozkan, G.; Ercisli, S.; Zeb, A.; Agar, A.; Sagbas, H.I.; Ilhan, G.; Gundogdu, M. Some Morphological and Biochemical Characteristics of Wild Grown Caucasian Whortleberry (Vaccinium arctostaphylos L.) Genotypes from Northeastern Turkey. Not. Bot. Horti Agrobot. 2019, 47, 378-383. [CrossRef]

3. Gecer, M.K.; Kan, T.; Gundogdu, M.; Ercisli, S.; Ilhan, G.; Sagbas, H.I. Physicochemical characteristics of wild and cultivated apricots (Prunus armeniaca L.) from Aras valley in Turkey. Genet. Resour. Crop Evol. 2020, 67, 935-945. [CrossRef]

4. Sahin, U.; Anapali, O.; Ercisli, S. Physico-chemical and physical properties of some substrates used in horticulture. Gartenbauwissenschaft. 2002, 67, 55-60.

5. Fu, L.; Xu, B.T.; Xu, X.R.; Qin, X.S.; Gan, R.Y.; Li, H.B. Antioxidant Capacities and Total Phenolic Contents of 56 Wild Fruits from South China. Molecules 2010, 15, 8602-8617. [CrossRef] [PubMed]

6. Li, Y.; Zhang, J.J.; Xu, D.P.; Zhou, T.; Zhou, Y.; Li, S.; Li, H.B. Bioactivities and Health Benefits of Wild Fruits. Int. J. Mol. Sci. 2016, 17, 1258. [CrossRef]

7. Ercisli, S.; Orhan, E.; Esitken, A.; Yildirim, N.; Agar, G. Relationships among some cornelian cherry genotypes (Cornus mas L.) based on RAPD analysis. Genet. Resour. Crop Evol. 2008, 55, 613-618. [CrossRef]

8. Yildiz, H.; Ercisli, S.; Hegedus, A.; Akbulut, M.; Topdas, E.F.; Aliman, J. Bioactive content and antioxidant characteristics of wild (Fragaria vesca L.) and cultivated strawberry (Fragaria ananassa Duch.) fruits from Turkey. J. Appl. Bot. Food. Qual. 2014, 87, 274-278.

9. Ercisli, S.; Esitken, A. Fruit characteristics of native rose hip (Rosa spp.) selections from the Erzurum province of Turkey. N. Z. J. Crop Hort. 2004, 32, 51-53. [CrossRef]

10. Tural, S.; Koca, I. Physico-chemical and antioxidant properties of cornelian cherry fruits (Cornus mas L.) grown in Turkey. Sci. Hortic. 2008, 116, 362-366. [CrossRef]

11. Korekar, G.; Dolkar, P.; Singh, H.; Srivastava, R.B.; Stobdan, T. Variability and the genotypic effect on antioxidant activity, total phenolics, carotenoids and ascorbic acid content in seventeen natural population of Seabuckthorn (Hippophae rhamnoides L.) from trans-Himalaya. LWT Food Sci. Technol. 2014, 55, 157-162. [CrossRef]

12. Hasbal, G.; Yilmaz-Ozden, T.; Can, A. Antioxidant and antiacetylcholinesterase activities of Sorbus torminalis (L.) Crantz (wild service tree) fruits. J. Food Drug Anal. 2015, 23, 57-62. [CrossRef] [PubMed]

13. TUBIVES. Turkish Plants Data Service (TÜBIVES). 2014. Available online: www.tu-bives.com (accessed on 25 June 2020$)$.

14. Wang, Y.; Jiang, H.; Peng, S.; Korpelainen, H. Genetic structure in fragmented populations of Hippophae rhamnoides ssp. sinensis in China investigated by ISSR and cpSSR markers. Plant Syst. Evol. 2011, 295, 97-107. [CrossRef]

15. Pop, R.M.; Weesepoel, Y.; Socaciu, C.; Pintea, A.; Vincken, J.-P.; Gruppen, H. Carotenoid composition of berries and leaves from six Romanian sea buckthorn (Hippophae rhamnoides L.) varieties. Food Chem. 2014, 147, 1-9. [CrossRef] [PubMed] 
16. Li, H.; Ruan, C.; Ding, J.; Li, J.; Wang, L.; Tian, X. Diversity in sea buckthorn (Hippophae rhamnoides L.) accessions with different origins based on morphological characteristics, oil traits, and microsatellite markers. PLoS ONE 2020, 15, e0230356. [CrossRef]

17. Zeb, A. Chemical and nutritional constituents of sea buckthorn juice. Pak. J. Nutr. 2004, 3, 99-106.

18. Aras, A.; Akkemik, Ü.; Kaya, Z. Hippophae rhamnoides L.: Fruit and seed morphology and its taxonomic problems in Turkey. Pak. J. Bot. 2007, 39, 1907-1916.

19. Rousi, A. The genus Hippophä L. A taxonomic study. Ann. Bot. Fennici 1971, 8, 177-227.

20. Sabir, S.M.; Maqsood, H.; Hayat, I.; Khan, M.Q.; Khaliq, A. Elemental and nutritional analysis of sea buckthorn (Hippophae rhamnoides ssp. turkestanica) berries of Pakistani origin. J. Med. Food 2005, 8, 518-522.

21. Singh, V. Geographical adaptation and distribution of seabuckthorn. In Seabuckthorn (Hippophae L.)—A Multipurpose Wonder Plant; Singh, V., Ed.; Indus Publishing Company: New Delhi, India, 2003; Volume I, pp. 21-34.

22. Ficzek, G.; Mátravölgyi, G.; Furulyás, D.; Rentsendavaa, C.; Jócsák, I.; Papp, D.; Simon, G.; Végvári, G.; Stéger-Máté, M. Analysis of bioactive compounds of three sea buckthorn cultivars (Hippophaë rhamnoides L. 'Askola', 'Leikora', and 'Orangeveja') with HPLC and spectrophotometric methods. Eur. J. Hortic. Sci. 2019, 84, 31-38. [CrossRef]

23. Teleszko, M.; Wojdylo, A.; Rudzinska, M.; Oszmianski, J.; Golis, T. Analysis of Lipophilic and Hydrophilic Bioactive Compounds Content in Sea Buckthorn (Hippophaë rhamnoides L.) Berries. J. Agric. Food Chem. 2015, 63, 4120-4129. [CrossRef] [PubMed]

24. Tiitinen, K.M.; Yang, B.; Haraldsson, G.G.; Jonsdottir, S.; Kallio, H.P. Fast analysis of sugars, fruit acids, and vitamin c in sea buckthorn (Hippophä̈ rhamnoides L.) varieties. J. Agric. Food Chem. 2006, 54, 2508-2513. [CrossRef] [PubMed]

25. Criste, A.; Urcan, A.C.; Bunea, A.; Furtuna, F.R.P.; Olah, N.K.; Madden, R.H.; Corcionivoschi, N. Phytochemical Composition and Biological Activity of Berries and Leaves from Four Romanian Sea Buckthorn (Hippophae Rhamnoides L.) Varieties. Molecules 2020, 25, 1170. [CrossRef]

26. Cenkowski, S.; Yakimishen, R.; Przybylski, R.; Muir, W.E. Quality of extracted sea buckthorn seed and pulp oil. Can. Biosyst. Eng. 2006, 48, 309-316.

27. Korekar, G.; Dolkar, P.; Singh, H.; Srivastava, R.B.; Stobdan, T. Genotypic and Morphometric Effect on Fruit Oil Content in Seventeen Natural Population of Seabuckthorn (Hippophae rhamnoides L.) from Trans-Himalaya. Natl. Acad. Sci. Lett. 2013, 36, 603-607. [CrossRef]

28. Zielinska, A.; Nowak, I. Abundance of active ingredients in sea-buckthorn oil. Lipids Health Dis. 2017, 16, 95. [CrossRef]

29. Tiitinen, K.M.; Hakala, M.A.; Kallio, H.P. Quality Components of Sea Buckthorn (Hippophae rhamnoides) Varieties. J. Agric. Food Chem. 2005, 53, 1692-1699. [CrossRef]

30. AOAC. Fat (Crude) or Ether Extract in Animal Feed. In Official Methods of Analysis of AOAC International; Horwitz, W., Ed.; AOAC International: Gaithersburg, MD, USA, 2000.

31. Melgarejo, P.; Salazar, D.M.; Artes, F. Organic acids and sugars composition of harvested pomegranate fruits. Eur. Food Res. Technol. 2000, 211, 185-190. [CrossRef]

32. Singleton, V.L.; Orthofer, R.; Lamuela-Raventos, R.M. Analysis of total phenols and other oxidation substrates and antioxidants by means of Folin-Ciocalteu reagent. In Oxidants and Antioxidants; Packer, L., Ed.; Elsevier: Amsterdam, The Netherlands, 1999; pp. 152-178.

33. Rodriguez-Delgado, M.Á.; Malovana, S.; Perez, J.; Borges, T.; Garcia-Montelongo, F.J. Separation of phenolic compounds by high-performance liquid chromatography with absorbance and fluorimetric detection. J. Chromatogr. 2001, 912, 249-257. [CrossRef]

34. Ozgen, M.; Reese, R.N.; Tulio, A.Z.; Scheerens, J.C.; Miller, A.R. Modified 2.2- azino-bis-3- ethylbenzothiazoline-6-sulfonic acid (ABTS) method to measure antioxidant capacity of selected small fruits and a comparison to ferric reducing antioxidant power (FRAP) and 2.2-diphenyl-1-picrylhdrazyl (DPPH) methods. J. Agric. Food Chem. 2006, 54, 1151-1157. [CrossRef]

35. Benzie, I.F.F.; Strain, J.J. The ferric reducing ability of plasma (FRAP) as a measure of "antioxidant power": The FRAP assay. Anal. Biochem. 1996, 239, 70-76. [CrossRef] [PubMed]

36. AOAC. Official Methods of Analysis; Association of Official Analytical Chemists: Rockville, MD, USA, 1995.

37. Fatima, T.; Snyder, C.L.; Schroeder, W.R.; Cram, D.; Datla, R.; Wishart, D.; Weselake, R.J.; Krishna, P. Fatty Acid Composition of Developing Sea Buckthorn (Hippophae rhamnoides L.) Berry and the Transcriptome of the Mature Seed. PLoS ONE 2012, 7, e34099. [CrossRef] [PubMed]

38. Sezen, I.; Ercisli, S.; Cakir, O.; Koc, A.; Temim, E.; Hadziabulic, A. Biodiversity and Landscape Use of Sea Buckthorn (Hippophae rhamnoides L.) in the Coruh Valley of Turkey. Erwerbs-Obstbau 2015, 57, 23-28. [CrossRef]

39. Zheng, J.; Yang, B.; Trepanier, M.; Kallio, H. Effects of genotype, latitude, and weather conditions on the composition of sugars, sugar alcohols, fruit acids, and ascorbic acid in sea buckthorn (Hippophaë rhamnoides ssp. mongolica) berry juice. J. Agric. Food Chem. 2012, 60, 3180-3189. [CrossRef] [PubMed]

40. Zheng, J.; Kallio, H.; Linderborg, K.; Yang, B. Sugars, sugar alcohols, fruit acids, and ascorbic acid in wild Chinese sea buckthorn (Hippophae rhamnoides ssp. sinensis) with special reference to influence of latitude and altitude. Food Res. Int. 2011, 44, $2018-2026$. [CrossRef]

41. Yadav, V.K.; Sah, V.K.; Singh, A.K.; Sharma, S.K. Variations in morphological and biochemical characters of seabuckthorn (Hippophae salicifolia D. Don) populations growing in Harsil area of Garhwal Himalaya in India. Trop. Agric. Res Ext. 2006, 9, 1-7.

42. Rongsen, L.U. Chemical composition of Hippophae fruits in China. In Proceedings of the International Symposium of SeaBuckthorn, Barnaul, Russia, 23-25 August 1993; pp. 398-412. 
43. Dhyani, D.; Maikhuri, R.K.; Dhyani, S. Seabuckthorn: An Underutilized Resource for the Nutritional Security and Livelihood Improvement of Rural Communities in Uttarakhand Himalaya. Ecol. Food Nutr. 2011, 50, 168-180. [CrossRef]

44. Singh, V.; Singh, R.K. Morpho-biochemical variations in seabuckthorn (Hippophae spp.) populations growing in Lahaul valley, dry temperate Himalayas. Indian For. 2004, 130, 663-672.

45. Heilsher, K.; Lorber, S. Processes for Cold Recovery of Clear Juice, Solids and Oil from Seabuckthorn Berries and Use of These Products. German Federal Republic Patent DE 4431394C1, 15 February 1996.

46. Chauhan, A.S.; Rekha, M.N.; Ramteke, R.S.; Eipeson, W.E. Preparation and quality evaluation of processed products from seabuckthorn (Hippophae rhamnoides L.) berries. Beverage Food World 2001, 1, 31-34.

47. Yao, Y.; Tigerstedt, P.M.A.; Joy, P. Variation of Vitamin C Concentration and Character Correlation between and within Natural Sea Buckthorn (Hippophae rhamnoides L.) Populations. Acta Agric. Scand. Sect. B Soil Plant Sci. 1992, 42, 12-17. [CrossRef]

48. Jalakas, M.; Kelt, K.; Kamp, K. The yield and fruit quality of sea buckthorn (Hippophae rhamnoides L.) after rejuvenation cutting. Agron. Res. 2003, 1, 31-36.

49. Kuhkheil, A.; Badi, H.N.; Mehrafarin, A.; Abdossi, V. Chemical constituents of sea buckthorn (Hippophae rhamnoides L.) fruit in populations of central Alborz Mountains in Iran. Res. J. Pharmacog. 2017, 4, 1-12.

50. Yang, B.; Kallio, H. Composition and physiological effects of sea buckthorn (Hippophae) lipids. Trends Food Sci. Technol. 2002, 13, 160-167. [CrossRef]

51. Ercisli, S.; Orhan, E.; Ozdemir, O.; Sengul, M. The genotypic effects on the chemical composition and antioxidant activity of sea buckthorn (Hippophae rhamnoides L.) berries grown in Turkey. Sci. Hortic. 2007, 115, 27-33. [CrossRef]

52. Yang, B.; Kallio, H.P. Fatty Acid Composition of Lipids in Sea Buckthorn (Hippophaë rhamnoides L.) Berries of Different Origins. J. Agric. Food Chem. 2001, 49, 1939-1947. [CrossRef]

53. Yang, B.; Halttunen, T.; Raimo, O.; Price, K.; Kallio, H. Flavonol glycosides in wild and cultivated berries of three major subspecies of Hippophaë rhamnoides and changes during harvesting period. Food Chem. 2009, 115, 657-664. [CrossRef]

54. Yang, B.; Zheng, J.; Kallio, H. Influence of origin, harvesting time and weather conditions on content of inositols and methylinositols in sea buckthorn (H. rhamnoides) berries. Food Chem. 2011, 125, 388-396. [CrossRef]

55. Saeidi, K.; Alirezalu, A.; Akbari, Z. Evaluation of chemical constitute, fatty acids and antioxidant activity of the fruit and seed of sea buckthorn (Hippophae rhamnoides L.) grown wild in Iran. Nat. Prod. Res. 2016, 30, 366-368. [CrossRef]

56. Rop, O.; Ercisli, S.; Mlcek, J.; Jurikova, T.; Hoza, I. Antioxidant and radical scavenging activities in fruits of 6 sea buckthorn (H. rhamnoides L.) cultivars. Turk J. Agric. For. 2014, 38, 224-232. [CrossRef]

57. Bittová, M.; Krejzová, E.; Roblová, V.; Kubán, P.; Kubán, V. Monitoring of HPLC profiles of selected polyphenolic compounds in sea buckthorn (Hippophä̈ rhamnoides L.) plant parts during annual growth cycle and estimation of their antioxidant potential. Cent. Eur. J. Chem. 2014, 12, 1152-1161. [CrossRef]

58. Di Mauro, M.D.; Giardina, R.C.; Fava, G.; Mirabella, E.F.; Acquaviva, R.; Renis, M.; D'Antona, N. Polyphenolic profile and antioxidant activity of olive mill wastewater from two Sicilian olive cultivars: Cerasuola and Nocellara etnea. Eur. Food Res. Technol. 2017, 243, 1895-1903. [CrossRef]

59. Donno, D.; Cerutti, A.K.; Prgomet, I.; Mellano, M.G.; Beccaro, G.L. Foodomics for mulberry fruit (Morus spp.): Analytical fingerprint as antioxidants' and health properties' determination tool. Food Res. Int. 2015, 69, 179-188. [CrossRef]

60. World Health Organization. Diet, Nutrition and the Prevention of Chronic Diseases, 29th ed.; World Health Organization: Geneva, Switzerland, 2003.

61. Fraga, C.G.; Croft, K.D.; Kennedy, D.O.; Tomás-Barberán, F.A. The effects of polyphenols and other bioactives on human health. Food Funct. 2019, 10, 514-528. [CrossRef]

62. Chen, C.; Xu, X.M.; Chen, Y.; Yu, M.Y.; Wen, F.Y.; Zhang, H. Identification, quantification and antioxidant activity of acylated flavonol glycosides from sea buckthorn (Hippophae rhamnoides ssp. sinensis). Food Chem. 2013, 141, 1573-1579. [CrossRef] [PubMed]

63. Makovics-Zsohár, N.; Hegedûs, A.; Stefanovits-Bányai, É.; Rédei, R.; Papp, N. The antioxidant capacity of sea buckthorn (Hippophae rhamnoides L.) berries depends on the genotype and harvest time. Int. J. Hortic. Sci. 2014, 20, 27-29. [CrossRef]

64. Li, T.S.C.; Beveridge, T.H.J.; Oomah, B.D. Nutritional and medicinal values. In Sea Buckthorn (Hippophae rhamnoides L.): Production and Utilization; Li, T.S.C., Beveridge, T., Eds.; NRC Research Press: Ottawa, ON, Canada, 2003; pp. 101-108.

65. Arimboor, R.; Kumar, K.S.; Arumughan, C. Simultaneous estimation of phenolic acids in sea buckthorn (Hippophaë rhamnoides) using RP-HPLC with DAD. J. Pharm. Biomed. Anal. 2008, 47, 31-38. [CrossRef] 